\title{
STIMULATING EFFECT OF SOLUBLE STARCH ON THE GROWTH OF MYCOBACTERIUM LEPRAEMURIUM IN CELL-FREE LIQUID MEDIUM ;
}

\author{
PRELIMINARY REPORT
}

\author{
MASAHIRO NAKAMURA \\ Department of Microbiology, Kurume University School of Medicine, \\ Kurume, 830, Japan
}

Received for publication December 11, 1979

\begin{abstract}
Effect of soluble starch on the growth of Mycobacterim lepraemurium in cell-free liquid medium was studied. The growth of $M$. lepraemurium was significantly stimulated when soluble starch was added to NC-5 medium at the final concentration of $0.2 \%$. A lot of clumps of bacterial cell was found in the smear for bacillary count at the cultivation period of 6 to 8 weeks at $30^{\circ} \mathrm{C}$.
\end{abstract}

\section{INTRODUCTION}

In the previous reports (Nakamura, 1972, 1974), it has been demonstrated that $M$. lepraemurium multiplies quantitatively in synthetic liquid media. These results was surely confirmed by Dhople and Hanks $(1974,1976,1977)$, by using ultrasensitive measurement of ATP. However, they pointed out the cessation of the growth at 6 or 8 weeks after cultivation. Recently, they tried to make an improved culture medium by substitution of malic acid, dithiothreitol, and $\boldsymbol{\delta}$-aminolevulinic acid for $\alpha$-ketoglutarate, cystein and hemin, respectively. They indicated that no cessation of the growth was observed in this medium (Dhople and Hanks, 1978).

On the other hand, very recently, the author found that possibly continuous growth of $M$. lepraemurium was observed when soluble starch was simply added to NC-5 medium (Nakamura, 1974) at an appropriate concentration.
The presenting paper is to report briefly growth curves and morphological features of $M$. lepraemurium grown in the culture medium which is tentatively referred to as NC-7 medium.

\section{MATERIALS AND METHODS}

M. lepraemurium : Hawaiian strain (M-65) was used. Bacterial suspension was made from a leproma developed in $\mathrm{C}_{3} \mathrm{H}$ mice previously experimentally infected. A leproma was homogenized by a glass-homogenizer, suspended in $\mathrm{M} / 30$ phosphate buffer ( $\mathrm{pH} 7.0$ ), and treated with $0.1 \%$ pronase at $37^{\circ} \mathrm{C}$ for $30 \mathrm{~min}$ for removing infected tissue. Pronase treated suspension was centrifuged at $3,000 \mathrm{rpm}$ for $30 \mathrm{~min}$, and the collected sediment was resuspended in buffer solution containing $0.1 \%$ bovine albumin V fraction (Armour Co.). A bacillary suspension thus prepared was used for inoculum. Inoculum size was usually $0.2 \mathrm{ml}$ of diluted suspension per 43 $\mathrm{ml}$ of the complete culture medium. 
Culture medium : Composition of EK (Enriched Kirchner) base is as follows ;

$\begin{array}{lc}\mathrm{KH}_{2} \mathrm{PO}_{4} & \cdots \cdots 6.0 \mathrm{~g} \\ \mathrm{Na}_{2} \mathrm{HPO}_{4} \cdot 12 \mathrm{H}_{2} \mathrm{O} & \cdots \cdots 7.0 \mathrm{~g} \\ \mathrm{Na} \text { citrate } & \cdots \cdots .7 \mathrm{~g} \\ \text { Sod. l-glutamate } & \cdots \cdots 10.0 \mathrm{~g} \\ \mathrm{MgSO}_{4} & \cdots \cdots 0.9 \mathrm{~g} \\ \text { Glucose } & \cdots \cdots .0 \mathrm{~g} \\ \text { Glycerine } & \cdots \cdots 30.0 \mathrm{ml} \\ \text { Adenosine } & \cdots \cdots 40.0 \mathrm{mg} \\ \text { Thymidine } & \cdots \cdots .60 .0 \mathrm{mg} \\ \text { Thioglycolate } & \cdots \cdots 60.0 \mathrm{mg} \\ \text { Aq } & \cdots \cdots 970.0 \mathrm{ml}\end{array}$

To make the complete medium, the procedure is as follows ;

1) $\mathrm{EK}$ base $25 \mathrm{ml}$ to $\mathrm{pH} 7.3$, Succinamide $21.0 \mathrm{mg}$ autoclaved.

2) To autoclaved EK base containing succinamide $(25 \mathrm{ml})$, the following Millipore-filtered agents are added aseptically.

\begin{tabular}{lr}
$12.5 \%$ Sod. pyruvate & $1.0 \mathrm{ml}$ \\
$0.25 \%$ Ca. pantothenate & $1.0 \mathrm{ml}$ \\
$5 \% \alpha$-ketoglutarate & $1.0 \mathrm{ml}$ \\
$0.5 \%$ Cytochrome c & $0.5 \mathrm{ml}$ \\
$0.02 \%$ Hemin & $1.5 \mathrm{ml}$ \\
$0.3 \%$ 1-cysteine $\mathrm{HCl}$ & $0.5 \mathrm{ml}$ \\
$0.03 \%$ NADH & $0.5 \mathrm{ml}$ \\
Aq & $7.0 \mathrm{ml}$ \\
Calf serum & $5.0 \mathrm{ml}$ \\
\multicolumn{1}{c}{ Total } & $43.0 \mathrm{ml}$
\end{tabular}

Addition of soluble starch : Soluble starch (agent for amylase test, Wako Co. Ltd., Japan) was added to EK base at the final concentrations of $0.2 \%$ to $0.8 \%$ as complete medium, and then sterilized by autoclaving.

Cultivation and assessment of the growth of $M$. lepraemurium: The complete medium containing $0.2 \mathrm{ml}$ of inoculum was distributed in $7 \mathrm{ml}$ into test tubes $(10.5 \times 1.5 \mathrm{~cm})$, and fitted with sterile rubber stoppers. Cultivation was carried out at $30^{\circ} \mathrm{C}$. Bacterial counts were enumerated by Hanks' method (1968).

\section{RESULTS}

Growth of $M$. lepraemurium:

Effect of soluble starch on the growth of $M$. lepraemurium was studied at the range of final concentrations from 0.2 to $0.8 \%$. The results indicated in Fig. 1 that the growth of $M$. lepraemurium was significantly stimulated by addition of soluble starch to NC-5 medium. Growth stimulating effect of soluble starch was observed in all the concentrations tested here. However, deposit of soluble starch took place when $0.8 \%$ was used. Therefore, it should be noted that optimal concentration of soluble starch was $0.2 \%$ or $0.4 \%$ at the final concentration.

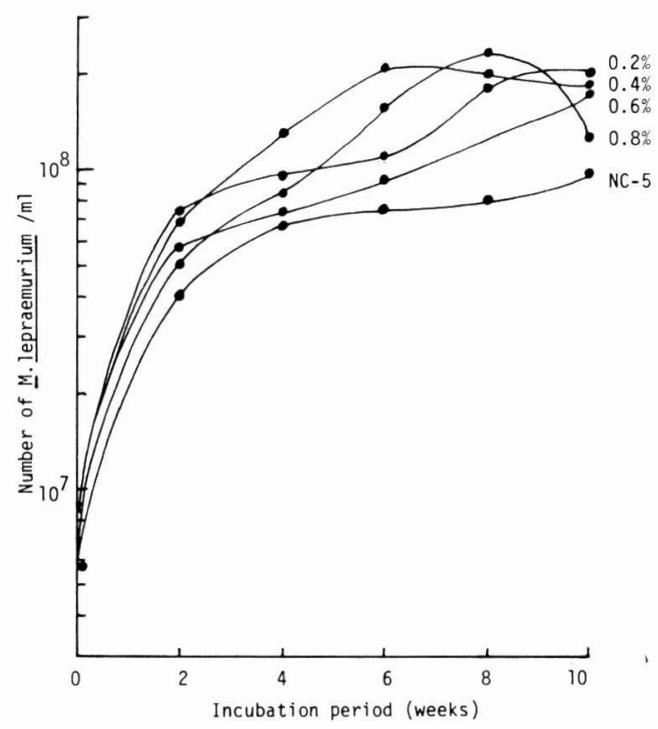

Fig. 1. Growth curves of M. lepraemurium in NC-5 medium containing soluble starch.

\section{Morphological feature :}

A lot of clumps appeared in bacillary counting smears made from all the tubes of NC-7 medium cultivated for 6 weeks at $30^{\circ} \mathrm{C}$. Morphological finding 


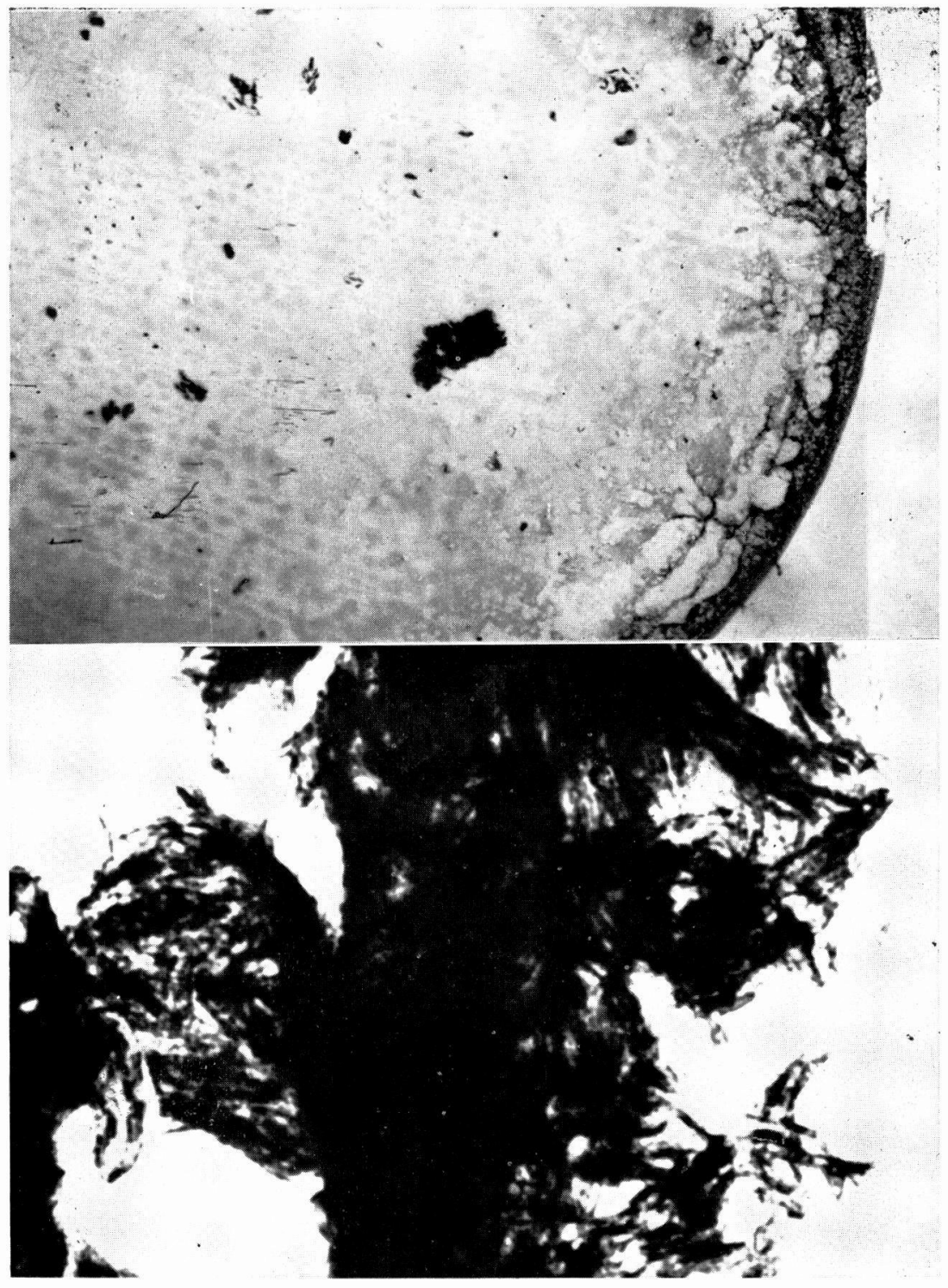

Fig. 2. Morphological feature of M. lepraemurium grown in NC-5 medium containing soluble starch (NC-7 medium). Clumps in a smear for bacillary count by Hanks method (low magnification ; $40 \times[$ upper $]$, high magnification $1,000 \times[$ lower $]$ ).

demonstrates a typical growth pattern of mycobacteria with cord formation. Each bacillary cell was solid, whereas no solid form was seen in NC-5 medium cultivated for corresponding period.

\section{DISCUSSION}

Evidence is presented that soluble starch stimulates the growth of $M$. lepraemurium. At present, chemical 
mechanism of the effect of soluble starch on the growth is not insolved. Studies on the effects of dextrin and maltose are necessary for further experiment. Presumably, soluble starch might have some interaction to cell wall synthesis of $M$. lepraemurium, because light microscopic pictures of cell structure in culture medium containing soluble starch illustrate solid form and to be more healthy than that of NC-5 medium. Electron microscopic observation and chemical analysis of cell wall of $M$. lepraemurium propagated in culture medium with soluble starch, as well as subcultivation trial are essential for future studies.

\section{ACKNOWLEDGMENTS}

This work was supported in part by the grants of the Naito Foundation and Ishibashi Foundation,

\section{REFERENCES}

Dhople, A. M. and Hanks, J. H. (1974). Validation of Nakamura's system for the microscopic growth of Mycobacterium lepraemurium. Leprosy Scientific Memoranda, Memo L-531.

Dhople, A.M. and HaNKs, J.H. (1976). Factors that influence the growth of $M$. lepraemurium in the Nakamura's system. Intern.

J. Leprosy, 44, 18-26.

DHOPLE, A. M. and Hanks, J.H. (1977). In vitro growth of $M$. lepraemurium, an obligate intracellular microbe. Science, 197, 379-381.

Dhople, A.M. and Hanks, J.H. (1978). Continuous in vitro growth of M.lepraemurium. Leprosy Scientific Memoranda, Memo L-938.

HaNKS, J. H. (1968). Microscopic counts of Mycobacteria, conversion factors for pinhead method. Intern. J. Leprosy, 36, 76-77.

NAKAmURA, M. (1972). Multiplication of $M$. lepraemurium in cell-free medium containing $\alpha$-ketoglutaric acid and cytochrome c. J. Gen. Microbiol, 73, 193-195.

NAKAmURA, M. (1974). Quantitative multiplication of $M$. lepraemurium in cell-free liquid medium (NC-5). J. Gen. Microbiol, 82, 385-391. 